\title{
WAR TIME HOUSING IN AMERICA ${ }^{1}$
}

\author{
BY JOHN IHLDER ${ }^{2}$ \\ Philadelphia
}

$I^{N}$ pre-war days we listed and discussed the reports ${ }^{3}$ on local housing conditions prepared for local committees and perhaps appended to them the names of a series of improved industrial villages created by corporations for their own employes and of one or two new and small limited dividend companies organized to improve the dwellings of wageearners in large cities. That was our seed time. Without it we should have entered the war totally unprepared to deal with one of the most difficult factors in our war industry problem-the housing of our workers. We should have provided far less effectively and with correspondingly greater loss through sickness and death, for the housing of our armies during their period of training.

Had we begun our planting ten years earlier or been granted ten years more for the seed to germinate, the story of our war-time housing would have been a different one. As it is we have been compelled to force the harvest, to do in a scant year and a half what should have taken several years, to thresh out at high speed and with minds pre-occupied by an overwhelming mass of detail, policies and problems that should have been settled before construction began. Even to-day we have not settled these fundamental questions; we are fighting the battles without having fully decided upon the plan of campaign. Our great good fortune is that we had available men who had studied the problems involved, though on limited fields, and like our army officers whose only practice had been with regiments and divisions, they are now demonstrating an ability to think and act in terms of a nation mobilized.

\section{NATIVE MIGRATION}

But this rapid progress makes futile any attempt to list and discuss individual communities as we did in the past. That way we are likely to miss seeing the forest because of the trees. A year and a half ago we were still thinking along old channels, though at slightly higher speed. The pre-war boom towns-Bridgeport, Flint, Hopewell, Penns Grovehad forced us to take new factors into our calculations. The virtual cessation of immigration from Europe, the migration of our native pop-

${ }^{1}$ See article "Wooden Cities":-The National Army Cantonments, by John Ihlder Volume VII, pp. 139.

${ }^{2}$ Secretary, Philadelphia housing association; representative U. S. housing corporation for Philadelphia; member, national city planning institute.

${ }^{3}$ See National Municipal Review. 
ulation to war industry centers, which reached a dramatic phase in the great negro migration of 1917 , introduced new values.

Our entrance into the war greatly increased this movement of native population. Certain sections of the country because of location, natural resources, established industries fitted to supply war essentials, drew workmen by the thousand and in some cases by the hundred thousand. At the same time the construction of new dwellings virtually ceased. Housing shortages in the war-industry centers became acute and private means were unable to meet the need. Yet unless the need were met, essential industries would halt because of lack of workers. We were compelled to think not in terms of a single manufacturing concern, even though it is as large as the U.S. Steel Corporation which built large towns, nor even in terms of a great industrial community like Philadelphia, which delights to call itself the workshop of the world, but in terms of a nation suddenly called upon to utilize all its resources to the utmost.

\section{WE ARE TOO BUSY FOR MANY REPORTS}

This change is reflected not so much in reports recently issued, for we are going too fast now to write many reports or to have them be little less than antiquated by the time they are published, but in the work that is being done. A year and a half ago we were issuing old-time reports; even in 1918 an occassional one appears from some still comparatively unhurried community, as that written by Robert E. Todd for the Des Moines housing commission. It is excellent of its kind. Especially effective are the illustrations. Mr. Todd has a way of writing his message on the photograph itself and using arrows to point to the exact spot to which he wishes to call attention that is much more effective than the usual description printed below a picture. It spoils the artistry, but it makes perfectly clear what he wants the reader to see. This report, like the interesting one on New Amsterdam, New York, written by Miss Udetta D. Brown, and that prepared for the city commission of Portland, Oregon, of which a summary is published in the Oregon Voter of July 20,1918, raise again the old wonder how the citizens of a community can read such descriptions and not act. After enumerating the windowless rooms, the foul toilets and insanitary plumbing which make the city of roses smell like something quite different to a large proportion of its population, the Voter gives one picture in detail:

\section{PORTLAND, OREGON, CONDITIONS}

In one two-room tenement lives a family of four, and there is no direct access to the outside air in either room. There is no sink in either room. Water has to be carried from a distance and the slops carried out an equal distance. At the end of the hall is an enclosed toilet, which ventilates into the same hallway that the two enclosed rooms depend upon for what air they get. A stifling stench pervades the entire premises-and little 
children breathe this from morning until night and then the whole family breathes it all night long.

Such is the home of one family in Portland, a rich, conservative city in a thinly settled commonwealth over which it may expand. Nor is this news to Portland, for it has been told similar stories during the past half dozen years. What Portland lacks is energy, not to overcome the greed and selfishness of a few landlords, but its own inertia and lazy acceptance of tradition and conditions.

\section{THE INTEREST OF THE DYNAMIC BUSINESS ELEMENT}

In other parts of the country war is supplying this energy, but accompanying it by a loss of effective power. Suddenly aroused to the need of more housing and better housing the dynamic business element has set itself to secure new dwellings of an improved type, but has become so absorbed in this that it neglects to inquire into the conditions of existing dwellings. Bridgeport, Connecticut, is still our best example, for there some attention was paid to existing buildings and the law was strengthened even though the greatest attention was given to new construction. Even in Bridgeport the emphasis was so much on one side that the plans for a new "model" apartment house had to be redrawn to comply with the law. Bridgeport had the great advantage of a prewar boom, however, which concentrated outside attention upon it and brought it criticism and suggestion in plenty. Later towns, like Lockport, New York, did not awaken until the housing shortage had begun to become national in its effects, and the efforts of its housing company failed to excite much more than local interest. Their successes or failures may or may not have interest to us after the war. If now, like Elizabethtown, New Jersey, they do succeed in erecting a few good dwellings, despite the high costs of labor and material and the difficulty of securing capital, they have a double satisfaction, they are helping to meet their own needs and at the same time aiding the nation-providing the workers who inhabit their new dwellings are engaged in essential industries. Five years ago we would have watched such co-operative efforts with the greatest interest as indications of a long step forward from ownership by a single firm. Now we do not know whether their contribution is anything more than the provision of a few more dwellings.

With these efforts of business groups to meet a need too great for the old-time competitive builder's resources may be classed the latest comers among company villages: Berwin, Tennessee, the garden village of the Connecticut Mills Company, Sawyer Park at Williamsport, Pennsylvania, the new developments at Dayton and Youngstown and Morgan Park. Some of these may have technical features calling for study; some may show the way to meet a practical difficulty-or a way sure to lead us into difficulty and therefore to be avoided. With them again may be 
classed an ever-increasing number of pamphlets on housing issued by concerns which have something to sell. They are a natural sequel to the old-time housing reports from which they draw a great part of their argument. Now that the business man has at last awakened to the need of good housing for wage-earners other business men are ready to sell it to him. The "ready-cut house" firms were the first in this field, but they now have competitors among dealers in metal lath, cement, lumber. Many of their publications are handsomely gotten out, as that of the Associated Metal Lath Manufacturers entitled As a Man Liveth. Industrial Houses of Concrete and Stucco by the Atlas Portland Cement. Company is more obviously a catalogue as its straightforward title indicates; while Housing and Industry by the National Lumber Manufacturers Association mingles housing philosophy with selling arguments. The National Fire Protective Association recognizes the new era by supplementing the building code of the National Board of Fire. Underwriters with a pamphlet on Recommendations on Emergency Housing, and wellknown firms like Ballinger and Perot and the Aberthaw Construction Company call attention to their services past and prospective by pamphlets on Modern Industrial Housing and Industrial Housing Problems. It is such as these that prove housing has ceased to be the fad of reformers and become the business of practical men. If only the practical men had arrived a few years earlier-but then they would not have been practical.

\section{NATIONAL hOUSING ASSOCIATION'S PUBLICATION}

How fast we are moving in housing is indicated by the Proceedings of the National Housing Association, held in October, 1917, and of the symposium on war housing, held in Philadelphia in February, 1918. The former shows us trying to get some understanding of our war housing problem and using as illustrative the experiences of small communities like Kenosha and Akron or the great, but foreign one of England. It contains discussions on reducing the cost of workmen's dwellings-reminiscent of a time when we dreamed of the $\$ 1,000$ house, while now we are building $\$ 5,000$ and $\$ 6,000$ houses; on the best house for the small wageearner, while now we are building for the wage-earner who gets from $\$ 50$ to $\$ 150$ a week-the small wage-earner must wait in an old building until after the war; on housing by employers, while now employers are calling upon the government to build; on the real estate man, while now the real estate man is closing his almost useless office to take part in Liberty Loan drives, for his houses are all rented. Whatever conclusion could have been reached then on such subjects must be modified now and probably still more modified before peace is signed-and after. Opinions are -or should be-based on facts.

Yet this volume has more than an historic interest for it contains some discussions on questions which have not undergone such violent change. 
We are still concerned as to which department of the city government shall enforce höusing laws, for city governments'still have their old powers over existing dwellings and even over new dwellings not built by a federal agency, We are still studying the problems of districting or zoning and still look to men like Lawson Purdy with his peace-time experience, for war has not changed the principles of city building and the federal authorities, immersed in detail, have not taken control of the development of cities as they have of the building and management of villages. Here the facts have not been greatly altered.

\section{WAR TIME HOUSING QUESTIONS}

The symposium, held four months later, shows the change. It was not a conference with prepared papers, but a series of snap-shot discussions. It did not deal with generalizations but with immediate problems: "To what extent shall war workers be housed in temporary barracksin permanent homes?" The answer given then is now being worked out, "In barracks only until permanent houses can be erected or where the need is temporary"; "shall houses for war workers be rented or sold?" a question that could not be answered. Is the industry permanent or will it decline after the war, compelling the present tenant to seek work elsewhere while a man of a different trade takes his dwelling? Should the wage-earner own his home? The two great federal agencies engaged in house building, the Emergency Fleet corporation and the U. S. housing corporation, have opposite opinions. Without prejudice to these opinions in general, they seem recently to have agreed that no houses should be sold now. "Shall we provide for housing many women workers?". One great war industry in the Philadelphia district, in a community where dwellings have been overfilled for months, is now seeking 4,000 women employes. It is not a question of shall but of must. So with the question "shall we encourage or discourage the "take a roomer campaign'?" Even at the time they were asked these questions as phrased had ceased to be pertinent. Only the remaining one remains live, "what is the best way to house the woman worker?" But it calls for a hundred answers. The woman worker, married, unmarried, mother and childless is with us as we never dreamed, in February, 1918, she would be. She works on railroad section gangs, in munition plants, she cleans city streets, and does home sewing for government arsenals. How shall she be housed?

\section{HOUSING STANDARDS}

Most of the war time changes in housing, great as they have been, only partially prepared for them as we were, are encouraging. Our unpreparedness has left us with fundamental questions unanswered. We are doing things not because we are convinced that they are the right things or that we are doing them in the right way, but simply because 
the war compelled us to do them in the first and quickest way we could. Yet day by day we are growing more confident that we shall find the answers. But in housing the war emphasis so far has been all on the side of construction. In that we have been able to secure the acceptance of good standards through the adoption of standards recommended for permanent industrial housing developments by the U. S. housing corporation, as well as through the work in both the housing corporation and the Emergency Fleet corporation of architects and housing specialists who know their importance. For our new federal housing we are also likely to have good maintenance. It is in the field of local government regulation that we have cause for most disquietude.

One effect of the war has been to divert interest from local questions. Moreover many of the best not only of our citizens, but of our local officials have answered the call to national and foreign service, leaving their home communities much the poorer. As a result the local work has suffered. Even with their best citizens all at home and with interest in local problems keen, the present would have proved a difficult time. Here is the continued work that has no glamor of war, though its performance is essential to our war power. The man or woman who continues at it must either realize its importance enough to sacrifice himself or be one who puts personal security and ease first. There are workers of both kinds in our public services to-day, but both the number and the power of the first have been much decreased by the call to the colors. Municipal work has slackened; departments are undermanned and often incompetently manned. This is true in war industry centers as in those where the only appeal to national service comes through the national government. And this is true in housing as it is in other branches of the local government. The machinery is still working, but at very low speed, in marked contrast to the feverish haste of the federal government's housing machinery. Yet in the war industry centers it is of quite as great importance. In Philadelphia there may and should be erected 15,000 to 20,000 new houses. That is the federal government's task. To do this task it has called in the best men from all over the country and they are working tremendously. In Philadelphia there are nearly 400,000 existing dwellings. To maintain them in proper sanitary condition would be a service many times greater in result than the erection of new dwellings, for they house many times the number of shipyard and munitions workers who will inhabit the government's dwellings. But that is old work, it has become more or less routine, and it has not the official stamp of being national service. In its performance there is none of the spirit that characterizes the federal work, a spirit that leads men to work day and night regardless of hours. Even in New Jersey, where the board of tenement house supervision has increased its work, there is no indication given by the latest annual report, that the board realizes the new duties 
and new opportunities of these days. Yet New Jersey at its northern and southern extremities comes within two of the great war industry districts. In New York a recent proposal by real estate interests that the tenement house department be abolished as a measure of economy and on the plea that it has done its work, was answered by a former commissioner by quoting figures showing the needs of the normal civil population. In Philadelphia, where the health of a vastly increased working population is of immediate and vital concern to the nation, the work is under the supervision of temporary appointees and no attempt has been made to do more than simply go through the established routine.

\section{FEDERAL INTEREST IN LOCAL CONDITIONS}

In grateful contrast to these cities is Buffalo, not because of what it has accomplished, but because its health and housing officials see their task in its true relation to our national program and desire to do their full duty. Like the other cities mentioned, Buffalo is a war industry center. The health department, under which is the enforcement of housing regulations, has made a thorough study of the situation which showed definitely the dearth of vacant dwellings, the falling off in new construction and the increasing population. It admits that under these conditions it cannot maintain all standards as it would and calls attention to the increase of families in lodgings. But it does maintain sanitary standards and in spite of the dearth of dwellings, to which its own report called attention, it vacated five tenement houses because of their insanitary condition.

In this it has the moral support of the federal authorities, for the U. S. housing corporation, whose purpose in being is to secure additional housing for war workers, constantly lays emphasis upon the need of making and keeping dwellings wholesome and habitable. So important do the federal authorities consider this that a short time ago Adjutant General H. B. Smith and Dr. W. F. King, of the Indiana health department, warned East Chicago that unless it improved its housing and sanitation martial law would be declared.

So far, however, the federal authorities have not interfered in local housing regulation except in the immediate neighborhood of large camps. There, as at Norfolk, they have made their influence felt. What they may do in the near future may be another story, unless the local authorities awaken to the fact that they too have a part to play in the war. For the increasing interest of the ordnance and navy departments in the health of workers on war contracts points in the same way as does that of the U.S. housing corporation, which already has made housing surveys of fifty-two cities in its search for available dwellings and which, despite its desire to secure accommodations, discards all insanitary houses, residence in which would reduce the productive efficiency of workers 
"Every effort," it states officially, "is being made to protect health and morals and gain comfort."

So for the period of the war we are likely to have an increase of federal initiative and control based upon the need for producing at our maximum. Until the end of September this was as far as any one in authority at Washington would go. Federal participation in housing was a war measure and even those who are working out the plans for managing the new industrial communities built with government money would say nothing publicly of what they thought should be done with those communities when war ends. One even declared that the subject is of no interest to him, that when peace is signed he will give up his position and that so far as he is concerned the government may scrap them all, as it can afford to do considering the small part they represent of the total war cost.

\section{WILL WAR COMMUNITIES BE SCRAPPED?}

But they will not be scrapped. Some of these developments are among the best examples in existence of industrial communities. They are a permanent addition to the national wealth. The time is at hand when, without relaxing our efforts to win a speedy and decisive military victory, we must begin to think of peace. We went into war unprepared and it has cost us billions more than it otherwise would. But war brings with it an exaltation that overrides obstacles. If we go into peace unprepared we shall unnecessarily waste more billions, and peace may bring with it a weariness and lassitude that can be overcome only by having a clearly defined purpose. Senator Weeks took the first step in his resolution advocating the appointment of a congressional committee on reconstruction, one of whose purposes will be a consideration of the housing problem.

When that committee, or some other agency, congressional or administrative, begins to study the proper disposition of the government's housing developments it will find one clear-cut proposal awaiting it in the plan put forth by the committee on new industrial towns, according to which they shall be owned by all their inhabitants as a group, not by some of them as individuals. 